\title{
INCOME OVER FEED COST PENGGEMUKAN SAPI OLEH KELOMPOK SARJANA MEMBANGUN DESA (SMD) DI KABUPATEN BANTUL DAN SLEMAN
}

\section{INCOME OVER FEED COST FOR BEEF CATTLE FATTENING BY SARJANA MEMBANGUN DESA (SMD) IN BANTUL AND SLEMAN DISTRICT}

\author{
Siti Muyasaroh ${ }^{1 *}$, I Gede Suparta Budisatria ${ }^{2}$, dan Kustantinah ${ }^{2}$ \\ ${ }^{1}$ SMK Negeri 2 Sukoharjo, Jawa Tengah, 57515 \\ ${ }^{2}$ Fakultas Peternakan, Universitas Gadjah Mada, Yogyakarta, 55281
}

Submited: 11 September 2014, Accepted: 20 May 2015

\begin{abstract}
INTISARI
Penelitian ini bertujuan untuk mengetahui pendapatan atas biaya pakan oleh peternak program Sarjana Membangun Desa (SMD) di Kabupaten Bantul dan Sleman. Materi yang digunakan adalah sapi Simmetal Peranakan Ongole di Kabupaten Bantul sebanyak 35 ekor dan di Kabupaten Sleman sebanyak 20 ekor. Parameter yang diamati adalah pertambahan bobot badan harian (PBBH), konversi pakan, feed cost per gain (FCG) dan income over feed cost (IOFC). Data pertambahan bobot badan harian (PBBH) dianalisis kovariansi dan efisiensi pakan, feed cost per gain (FCG) serta income over feed cost (IOFC) dianalisis variansi Completely Randomized Design (CRD) pola searah. Data yang diperoleh meliputi rerata $\mathrm{PBBH}$, konversi pakan, feed cost per gain dan income over feed cost sapi yang dipelihara peternak program

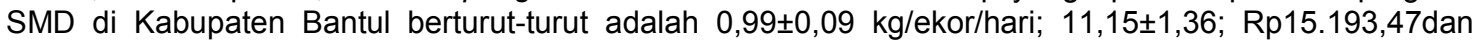
Rp9.892,32 sedangkan di Kabupaten Sleman berturut-turut adalah 0,65 $\pm 0,09$ kg/ekor/hari; 13,86 $\pm 2,03$; Rp9.615,67 dan Rp10,094.44. Pendapatan atas biaya pakan kelompok SMD di Kabupaten Sleman lebih besar daripada Bantul. Usaha penggemukan ini belum memiliki nilai ekonomi yang tinggi.
\end{abstract}

(Kata kunci: Pendapatan atas biaya pakan, Sapi potong, Sarjana Membangun Desa (SMD)

\section{ABSTRACT}

The objective was to analyze income over feed costs (IOFC) for beef cattle fattening by Sarjana Membangun Desa (SMD) in Bantul and Sleman district. The materials of the research were 35 head SimPo breed in Bantul district and 20 head SimPo in Sleman district. Collected parameter are average daily gain (ADG), feed conversion, feed cost per gain (FCG) and income over feed costs (IOFC). Average daily gain was analysed using covariance analysis with intial body weight as covariates. Feed conversion and feed cost per gaain were analysed using one way analysis of Completely Randomized Design (CRD). The average of $A D G$, feed conversion, feed cost per gain and income over feed cost of beef cattle in Bantul district were 0.99 $\pm 0.09 \mathrm{~kg} / \mathrm{head} /$ day; $11.15 \pm 1.36$; Rp15,193.47 and Rp9,892.32 respectively, while in Sleman district, it was $0.65 \pm 0.09 \mathrm{~kg} / \mathrm{head} /$ day; $13.86 \pm 2.03 ; \mathrm{Rp9}, 615.67$ and $R p 10,094.44$ respectively. Income over feed costs SMD groups in the district of Sleman, Bantul outweigh. This fattening yet has a high economic value.

(Key words: Beef cattle, Income over feed cost, Sarjana Membangun Desa)

\footnotetext{
* Korespondensi (corresponding author):

Telp. +62 81578033951

E-mail: muyasaroh1983@gmail.com
} 


\section{Pendahuluan}

Peternakan sebagai salah satu penyedia sumber protein hewani memiliki andil yang besar dalam pemenuhan kebutuhan pangan terutama daging. Salah satu usaha untuk memenuhi kebutuhan daging tersebut adalah usaha penggemukan sapi. Usaha penggemukan sapi memerlukan pakan yang berkualitas dan berkuantitas tinggi (Basuki, 2000). Sarjana Membangun Desa (SMD) merupakan salah satu kegiatan Direktorat Jenderal Peternakan Departemen Pertanian dalam upaya memberdayakan kelompok tani ternak untuk memajukan usahanya yang dilakukan dengan menempatkan tenaga Sarjana Peternakan atau Kedokteran Hewan maupun D-3 IImuilmu Peternakan sebagai anggota dalam kelompok tersebut di pedesaan (Direktorat Jenderal Peternakan, 2007). Peran SMD dalam kelompok di samping sebagai anggota, pendamping, juga sebagai pelaku usaha, akan selalu memotivasi dan menata usahanya dengan memanfaatkan sumber daya lokal dan menerapkan teknologi sesuai dengan ilmu pengetahuan yang dimiliki, sehingga seorang SMD harus bisa meningkatkan kesejahteraan anggotanya. Salah satu cara adalah dengan menekan biaya terutama biaya pakan dengan memanfaatkan sumber daya lokal dan menerapkan teknologi sesuai dengan ilmu pengetahuan. Salah satu usaha SMD adalah usaha penggemukan sapi potong.

Usaha penggemukan sapi potong merupakan usaha untuk mendapatkan kenaikan bobot badan sapi yang tinggi dengan biaya yang minimal. Perhitungan ekonomi pada usaha penggemukan sapi potong hanya menghitung pendapatan usaha tani belum memperhitungkan biaya pakan. Biaya pakan harus diperhitungkan karena biaya pakan merupakan $70 \%$ dari biaya total usaha penggemukan. Nilai income over feed costs (IOFC) merupakan selisih antara pendapatan dengan biaya pakan (Mayulu et al., 2009). Penghitungan IOFC dilakukan untuk mengetahui nilai ekonomis pakan terhadap pendapatan petani ternak sapi potong. Pendapatan merupakan perkalian antara produksi peternakan atau pertambahan bobot badan harian dengan harga jual, sedangkan biaya pakan adalah biaya yang dikeluarkan untuk menghasilkan pertambahan bobot badan ternak (Prawirokusumo, 1990). IOFC adalah konsep untuk mengetahui analisis usaha sebagai indikator awal kegiatan penggemukan sapi potong dalam jangka pendek (Priyanti et al., 2012). Biaya pakan berkisar antara $60-80 \%$ dari biaya total produk (Astutik et al., 2002). Kajian tentang pakan untuk meningkatkan pendapatan dilaporkan pula oleh Thanh dan Suksombat (2015) bahwa penggantian pakan mempengaruhi IOFC dan pendapatan peternak. Prasetiyono et al. (2007) menyatakan bahwa sapi potong yang diberi pakan jerami padi fermentasi dengan dedak halus secara ad libitum dan ketela pohon fermentasi memberikan nilai IOFC sebesar Rp7.500 ekor/hari. Hasil penelitian Mayulu et al. (2009) memperoleh IOFC sapi Simmental Peranakan Ongole (SimPO) sebesar Rp18.391/ekor/hari. Usaha pemeliharaan sapi bakalan atau usaha penggemukan harus memperhatikan pemilihan bakalan, pakan, lama pemeliharaan dan biaya produksi lainnya sehingga mendapatkan keuntungan yang maksimal (Hasbullah, 2003). Hal inilah yang menjadi dasar untuk mengetahui pendapatan atas biaya pakan usaha penggemukan pada kelompok SMD di Kabupaten Bantul dan Sleman.

\section{Materi dan Metode}

Penelitian ini dilaksanakan di Kabupaten Bantul dan Kabupaten Sleman, Daerah Istimewa Yogyakarta. Lokasi penelitian ditentukan secara purposive sampling method. Pertimbangan yang digunakan dalam penelitian ini adalah lokasi usaha penggemukan sapi potong dan peternak yang merupakan kelompok binaan Sarjana Membangun Desa.

\section{Materi}

Materi yang digunakan adalah 15 ekor sapi SimPO jantan di kelompok Andini Mukti dan 20 ekor sapi SimPO jantan di kelompok Mekar Barokah Kabupaten Bantul, serta 10 ekor sapi SimPO jantan di kelompok Rukun Tani Santosa dan 10 ekor sapi SimPO jantan di kelompok Tani Lembu Krendosari di Kabupaten Sleman. Alat yang digunakan timbangan ternak FHK yang mempunyai kapasitas 1.000 kg untuk menimbang sapi, dan timbangan merk Healthy, kapasitas $25 \mathrm{~kg}$ untuk menimbang pakan dan sisa pakan.

\section{Metode}

Metode yang digunakan dalam penelitian ini adalah kombinasi antara metode 
survei yang bersifat deskriptif dan analitis serta pengamatan langsung di lapangan. Konsumsi pakan diperoleh dengan melakukan penimbangan pakan sebelum diberikan pada ternak, sedangkaan sisa pakan ditimbang pada pagi hari berikutnya. Pengukuran konsumsi pakan dilakukan selama tiga bulan. Pertambahan bobot hidup harian diukur pada awal bulan setiap bulan selama tiga bulan. Konversi pakan dihitung menggunakan rumus rerata konsumsi bahan kering (BK) per hari dibagi dengan pertambahan bobot bahan harian (PBBH). Pendapatan atas biaya pakan atau IOFC dihitung dengan mengalikan harga sapi hidup per kilogram dengan $\mathrm{PBBH}$ dikurangi harga pakan per hari.

\section{Analisis data}

Data konsumsi bahan kering, konversi pakan, feed cost per gain, dan IOFC, dianalisis dengan menggunakan analisis variansi Completely Randomized Design (CRD) pola searah, sedangkan untuk $\mathrm{PBBH}$ digunakan analisis kovariansi dengan bobot awal sebagai kovariat (Astuti, 1980).

\section{Hasil dan Pembahasan}

\section{Konsumsi bahan kering}

Hasil analisis statistik menunjukkan bahwa konsumsi BK yang diberikan berbeda nyata $(P<0,05)$ antara sapi SimPO yang dipelihara oleh peternak SMD di Kabupaten Bantul dan Kabupaten Sleman. Rerata konsumsi bahan kering sapi SimPO berturutturut adalah $135,13 \pm 9,23 \mathrm{~g} / \mathrm{kgBB}^{0,75}$ dan $112,44 \pm 4,58 \mathrm{~g} / \mathrm{kgBB}^{0,75}$ di kelompok SMD Kabupaten Bantul dan Sleman. Perbedaan yang nyata ini disebabkan karena kualitas bahan pakan yang diberikan di kelompok SMD Kabupaten Bantul lebih baik dibandingkan dengan Sleman. Hal tersebut sesuai dengan pendapat Kartadisastra (2004) yang mengemukakan bahwa tinggi rendahnya konsumsi pakan ternak ruminansia dipengaruhi oleh temperatur lingkungan, palatabilitas, selera, status fisiologis, konsentrasi nutrisi, bentuk pakan, bobot tubuh, dan produksi. Hasil penelitian ini,konsumsi bahan kering lebih rendah dari hasil penelitian De Carvalho et al. (2010) yang mendapatkan konsumsi BK sapi SimPO yang dipelihara secara feedlot sebesar 146,36 $\mathrm{g} / \mathrm{kg} / \mathrm{BB}^{0,75}$, sedangkan Afgrinuryudi (2011) memperoleh konsumsi BK sebesar 110,29 $\mathrm{g} / \mathrm{kg} / \mathrm{BB}^{0,75}$ yang hampir sama dengan konsumsi BK sapi di Kabupaten Sleman. Konsumsi BK secara keseluruhan sudah terpenuhi bila dibandingkan dengan konsumsi BK yang dianjurkan oleh NRC (1976) untuk sapi yang mempunyai bobot awal $\geq 350 \mathrm{~kg}$ adalah 112,72 $\mathrm{g} / \mathrm{kgBB}^{0,75}$. Peningkatan konsumsi bahan kering juga dipengaruhi oleh tingkat pemberian konsentrat. Pakan yang diberikan terdiri dari hijauan dan konsentrat. Pakan konsentrat yang diberikan di Kabupaten Bantul tersusun atas bekatul (20\%), kulit kedelai (20\%) dan ampas ketela (60\%). Pakan yang diberikan kelompok SMD di Kabupaten Sleman terdiri dari jerami dan konsentrat. Konsumsi bahan kering meningkat linier dengan semakin meningkatnya pemberian pakan konsentrat (Siregar, 2001). Pakan yang diberikan di kelompok SMD Kabupaten Bantul dan Kabupaten Sleman diberikan secara sistem feedlot. Sistem feedlot adalah pemberian pakan pada ternak dalam jumlah yang mencukupi selama periode tertentu untuk mempercepat dan meningkatkan produksi dengan sistem dry lot fattening (pemberian pakan dengan jumlah konsentrat yang jumlahnya lebih banyak daripada hijauan (Sarwono dan Arianto, 2001).

Parakkasi (1995) menyatakan bahwa ternak yang mempunyai kapasitas konsumsi tinggi, maka produksinyapun akan relatif lebih tinggi dibandingkan dengan ternak yang mempunyai kapasitas konsumsi rendah, walaupun diberikan pakan dengan kualitas dan kuantitas yang sama.

\section{Pertambahan bobot badan harian}

Pertumbuhan pada umumnya dinyatakan dengan mengukur pertambahan bobot badan karena mudah dilakukan dan dinyatakan sebagai PBBH atau average daily gain (Tillman et al.,1998). Sapi SimPO yang dipelihara oleh SMD di Kabupaten Bantul berjumlah 35 ekor sedangkan di Kabupaten Sleman berjumlah 20 ekor dengan bobot badan awal 354,54 $\pm 10,89 \mathrm{~kg}$ dan $335,8 \pm 11,22 \mathrm{~kg}$. Pertambahan bobot badan harian sapi SimPO di Kabupaten Bantul dan Sleman tersaji pada Tabel 1.

Pada Tabel 1 menunjukkan bahwa sapi yang dipelihara peternak kelompok SMD di Kabupaten Bantul mempunyai PBBH yang lebih tinggi dibandingkan dengan sapi yang dipelihara peternak SMD di Kabupaten Sleman. Perbedaan ini disebabkan karena perbedaan kualitas pakan yang diberikan serta sistem pemeliharaan. Umumnya, $\mathrm{PBBH}$ 
Tabel 1. Konsumsi pakan, pertambahan bobot badan harian $(\mathrm{PBBH})$, konversi pakan, feed cost per gain dan income over feed cost di Kabupaten Bantul dan Sleman

(feed consumption, average daily gain, feed conversion, feed cost per gain and income over feed cost in Bantul and Sleman district)

\begin{tabular}{lcc}
\hline \hline \multicolumn{1}{c}{ Variabel (variables) } & \multicolumn{2}{c}{ Lokasi (location) } \\
\cline { 2 - 3 } & \multicolumn{1}{c}{ Bantul } & Sleman \\
\hline Konsumsi bahan kering (g/kg BB $\left.{ }^{0,75}\right)$ (consumption dry matter (g/kgbody & & \\
weight $\left.^{0,75}\right)$ ) & $135,13 \pm 9,23^{\mathrm{a}}$ & $112,44 \pm 4,58^{\mathrm{b}}$ \\
PBBH (kg/ekor/hari) (average daily gain (kg/head/day)) & $0,99 \pm 0,09^{\mathrm{a}}$ & $0,65 \pm 0,99^{\mathrm{b}}$ \\
Konversi pakan (feed conversion) & $11,15 \pm 1,36^{\mathrm{b}}$ & $13,86 \pm 2,03^{\mathrm{a}}$ \\
Feed cost per gain $(\mathrm{Rp})$ & $15.193,47^{\mathrm{a}}$ & $9.615,67^{\mathrm{b}}$ \\
Income over feed cost $(\mathrm{Rp})$ & $9.892,32^{\mathrm{b}}$ & $10.094,44^{\mathrm{a}}$ \\
\hline a,b Superskrip yang berbeda pada baris yang sama menunjukkan perbedaan yang nyata $(\mathrm{P}<0,05)($ different \\
superscripts at the same row indicate significant differences $(P<0.05)$ ).
\end{tabular}

sapi SimPO yang dipelihara secara intensif cukup tinggi, yaitu di atas $1 \mathrm{~kg} / \mathrm{ekor} / \mathrm{hari}$. Pemeliharaan secara intensif merupakan pemeliharaan yang dilakukan dengan memberikan pakan kualitas tinggi. Hasbullah (2003) dalam penelitiannya mendapatkan $\mathrm{PBBH}$ sapi simPO sebesar 1,22 kg/ekor/hari. Lestari (2009) dalam penelitiannya mendapatkan bahwa sapi SimPO yang digemukkan secara feedlot, mampu menghasilkan $\mathrm{PBBH}$ sebesar 1,28 kg/ekor/hari, sedangkan de Carvalho (2010), dengan sistem pemeliharaan secara feedlot memperoleh PBBH sapi SimPO sebesar 1,19 kg/ekor/hari. Sebaliknya, pada tingkat peternak kecil dan sistem pemeliharaan yang sederhana, $\mathrm{PBBH}$ sapi SimPO yang dihasilkan juga relatif rendah. Sebagai contoh, Lestari (2009) dalam penelitiannya pada tingkat peternak kecil memperoleh $\mathrm{PBBH}$ sapi SimPO hanya 0,65 kg/ekor/hari. Dibandingkan dengan hasil penelitian de Carvalho (2010), maka PBBH sapi SimPO yang dipelihara oleh peternak SMD Kabupaten Bantul dan Sleman pada penelitian ini masih lebih rendah. Hal ini disebabkan karena perbedaan sistem pemeliharaan, terutama pada peternak SMD Kabupaten Sleman. Pada peternak SMD Kabupaten Bantul, meskipun pemeliharaan sudah secara intensif, tetapi imbangan antara pakan konsentrat dengan hijauan masih belum sesuai dengan imbangan ideal dalam sistem feedlot yaitu $80 \%$ konsentrat dan $20 \%$ hijauan, sehingga PBBH yang dihasilkan juga tidak maksimal dibandingkan dengan penelitian-penelitian lainnya.

\section{Konversi pakan}

Berdasarkan hasil analisis statistik dapat dilihat bahwa terdapat perbedaan yang nyata $(P<0,05)$ untuk konversi pakan sapi
SMD di Kabupaten Bantul dan Sleman sebesar $11,15 \pm 1,36$ vs $13,86 \pm 2,03$. Sapi yang dipelihara oleh kelompok SMD Kabupaten Bantul, memiliki konversi pakan lebih baik dibandingkan dengan sapi yang dipelihara oleh peternak kelompok SMD Kabupaten Sleman, hal ini berarti bahwa sapi-sapi tersebut mempunyai efisiensi pemanfaatan pakan yang lebih tinggi untuk menghasilkan pertambahan bobot badan. Perbedaan ini dipengaruhi oleh konsumsi pakan dan $\mathrm{PBBH}$ yang dihasilkan. Sapi SimPO yang dipelihara oleh peternak kelompok SMD di Kabupaten Bantul memiliki konsumsi pakan dan $\mathrm{PBBH}$ yang lebih tinggi daripada Kabupaten Sleman. Hal ini sesuai dengan pernyataan Jesse et al. (1976) bahwa peningkatan efisiensi pakan dapat menurunkan biaya pakan yang dikeluarkan dan akan menghasilkan efisiensi yang lebih baik pada sistem produksi secara keseluruhan. Chestworth (1992) menyatakan bahwa perbaikan efisiensi pemanfaatan pakan akan meningkatkan kesempatan peternak untuk mendapatkan keuntungan yang lebih besar.

Hasil penelitian Afgrinuryudi (2011) memperoleh konversi pakan sapi SimPO yang dipelihara secara feedlot sebesar 9,95, sedangkan menurut Tillman et al. (1998) nilai konversi pakan yang ideal pada sapi potong adalah sekitar 9, jika dibandingkan dengan hasil penelitian yang terdahulu, maka nilai konversi pakan sapi SimPO yang dipelihara oleh peternak SMD, baik di Bantul maupun Sleman pada penelitian ini kurang ideal, hal ini menandakan bahwa efisiensi pemanfaatan pakan relatif rendah. Perbedaan ini disebabkan karena selain jenis bahan pakan yang dikonsumsi berbeda, juga disebabkan karena perbedaan kemampuan ternak untuk mencerna bahan pakan, kecukupan zat pakan untuk kebutuhan pertumbuhan, hidup 
pokok dan fungsi tubuh lainnya, sesuai dengan pernyataan Basuki (2000).

\section{Feed cost per gain}

Tabel 1 menunjukkan bahwa feed cost per gain (FCG) sapi SimPO kelompok SMD Kabupaten Sleman lebih efisien daripada sapi SimPO di Kabupaten Bantul, karena sapi SimPO di Kabupaten Sleman hanya membutuhkan biaya pakan sebesar Rp9.615,67 untuk menghasilkan $1 \mathrm{~kg}$ bobot badan, sedangkan sapi SimPO di Bantul membutuhkan biaya pakan Rp15.193,47. Terdapat perbedaan yang nyata $(\mathrm{P}<0,05)$ antara $\mathrm{FCG}$ sapi SimPO di Kabupaten Sleman dan Bantul. Perbedaan yang nyata ini disebabkan karena adanya perbedaan konsumsi pakan, $\mathrm{PBBH}$, dan harga pakan. Sapi SimPO di Bantul, meskipun menghasilkan $\mathrm{PBBH}$ yang lebih tinggi dibandingkan di Sleman, akan tetapi konsumsi pakan juga tinggi. Selain itu jenis pakan yang diberikan oleh peternak di Kabupaten Bantul (konsentratnya terdiri dari bekatul, ampas tahu, dan kulit kedelai) merupakan jenis pakan dengan harga yang relatif tinggi jika dibandingkan dengan jenis pakan di Kabupaten Sleman (konsentrat dan jerami padi). Terlihat bahwa faktor utama yang mempengaruhi tingginya FCG di Kabupaten Bantul adalah karena harga pakan yang tinggi. Selain itu, meningkatnya biaya pakan pada usaha penggemukan lebih disebabkan karena pakan yang diberikan belum tentu dikonsumsi ternak sesuai dengan yang diharapkan, sehingga berpengaruh terhadap $\mathrm{PBBH}$ yang dihasilkan dan dampaknya biaya yang dikeluarkan menjadi meningkat. Jesse et al. (1976) menyatakan bahwa pemberian pakan yang berkualitas tinggi pada usaha penggemukan sapi potong dapat meningkatkan konsumsi pakan, laju pertumbuhan, efisiensi pakan, persentase karkas dan lemak, serta menurunkan alokasi biaya pakan pada setiap unit pertambahan bobot badan. Namun demikian, pemberian pakan berkualitas tinggi harus diimbangi dengan harga pakan yang kompetitif untuk meminimalisir tingginya FCG. Untuk mendapatkan FCG rendah maka pemilihan bahan pakan penyusun ransum harus semurah mungkin dan tersedia secara kontinyu atau dapat juga menggunakan limbah pertanian yang tidak kompetitif (Basuki, 2000), meskipun biaya pakan yang murah belum tentu menghasilkan FCG yang rendah (Sagala, 2011).
Taylor (1984) menyatakan bahwa FCG merupakan perhatian yang paling utama dalam usaha penggemukan sapi, ada banyak faktor yang mempengaruhi FCG yaitu salah satunya efisiensi pakan. Selanjutnya dinyatakan bahwa PBBH dan efisiensi pakan sangat berhubungan. Sapi yang mempunyai $\mathrm{PBBH}$ yang lebih tinggi akan lebih efisien dalam penggunaan pakannya.

Feed cost per gain sapi SimPO di kelompok SMD Bantul maupun Sleman mempunyai nilai yang lebih rendah dari pada hasil penelitian de Carvalho (2010) yang memperoleh nilai FCG sebesar Rp18.344,00. Perbedaan ini disebabkan karena jenis pakan dan harga dari bahan pakan yang berbeda.

\section{Income over feed cost}

Income over feed costs (IOFC) merupakan selisih antara penerimaan dengan biaya pakan (Mayulu et al., 2009). Penerimaan merupakan perkalian antara produksi peternakan atau $\mathrm{PBBH}$ dengan harga jual, sedangkan biaya pakan adalah biaya yang dikeluarkan untuk menghasilkan pertambahan bobot badan ternak (Prasetiyo, 2013). Income over feed costs (IOFC) adalah konsep untuk mengetahui analisis usaha sebagai indikator awal kegiatan penggemukan sapi potong dalam jangka pendek (Priyanti et al., 2012). Perhitungan IOFC dilakukan untuk mengetahui nilai ekonomis pakan terhadap pendapatan petani ternak sapi potong. Income over feed costs (IOFC) dilakukan karena biaya pakan berkisar antara $60-80 \%$ dari biaya total produk (Astutik et al., 2002).

Pada Tabel 1 menunjukkan bahwa IOFC sapi SimPO di SMD Kabupaten Sleman lebih besar daripada sapi SimPO di SMD Kabupaten Bantul. Perbedaan tersebut dikarenakan biaya pakan di Kabupaten Sleman lebih rendah daripada di Bantul. Selain harga pakan yang berbeda, $\mathrm{PBBH}$ ternak juga berpengaruh terhadap IOFC. Hal ini sesuai dengan pendapat Weller (1994) yang menyatakan bahwa PBBH berpengaruh sangat tinggi terhadap efisiensi pakan untuk ternak yang baru tumbuh. Hasil penelitian Mayulu et al. (2009) memperoleh IOFC sapi SimPO sebesar Rp18.391,00/ekor/hari, jika dibandingkan dengan hasil penelitian yang terdahulu, maka IOFC sapi SimPO yang dipelihara oleh peternak SMD baik di Bantul maupun Sleman pada penelitian ini masih rendah. Income over feed cost (IOFC) sapi SimPO yang dipelihara oleh peternak SMD 
baik di Bantul maupun Sleman mempunyai nilai yang lebih tinggi, bila dibandingkan dengan hasil penelitian Prasetiyono et al. (2007) yang menyatakan bahwa sapi potong yang diberi pakan jerami padi fermentasi dedak halus secara ad libitum dan ketela pohon fermentasi memberikan nilai IOFC sebesar Rp7.500,00 ekor/hari.

\section{Kesimpulan}

Dari hasil penelitian yang telah dilakukan dapat disimpulkan bahwa pendapatan atas biaya pakan kelompok SMD di Kabupaten Sleman lebih besar daripada Bantul. Pendapatan atas biaya pakan pada sapi SimPO yang dipelihara peternak SMD Kabupaten Bantul dan Sleman sebesar Rp9.892,32 ekor/hari dan Rp10.094,44 ekor/hari. Usaha penggemukan ini belum memiliki nilai ekonomi yang tinggi.

\section{Ucapan Terima Kasih}

Puji syukur atas rahmat dan hidayahNya sehingga telah terselesainya makalah ini. Kami ucapkan terima kasih kepada anggota kelompok ternak Andini Mukti dan Mekar Barokah di Kabupaten Bantul dan anggota kelompok Rukun Tani Sentosa dan Lembu Kredosari di Kabupaten Sleman serta berbagai pihak yang telah membantu penelitian.

\section{Daftar Pustaka}

Afgrinuryudi, D. 2011. Pertumbuhan sapi jantan Peranakan Ongole dan persilangan Simmental-Peranakan Ongole yang dipelihara secara feedlot. Skripsi Fakultas Peternakan, Universitas Gadjah Mada, Yogyakarta.

Astuti, M. 1980. Statistik. Fakultas Peternakan, Universitas Gadjah Mada, Yogyakarta.

Astutik, S. I. B., M. Arifin, dan W. S. Dilaga. 2002. Respon sapi PO berbasis pakan jerami padi terhadap berbagai formula "urea molases blok". Seminar Nasional Teknologi Peternakan dan Veteriner. Fakultas Peternakan, Universitas Diponegoro, Semarang.
Basuki, P. 2000. Kajian optimalisasi usaha penggemukan sapi (feedlot) melalui manipulasi pakan, pertumbuhan kompensatori, dan periode waktu penggemukan. Disertasi Institut Pertanian Bogor, Bogor.

Chestworth, J. 1992. Ruminant Nutrition. Macmillian Education LTD. London and Basingtoke.

De Carvalho, M. D. C., Soeparno, dan N. Ngadiyono. 2010. Pertumbuhan dan produksi karkas sapi Peranakan Ongole dan Simmental Peranakan Ongole jantan yang dipelihara secara feedlot. Buletin Peternakan 34: 38-46.

Direktorat Jenderal Peternakan. 2007. Petunjuk Pelaksanaan Program Sarjana Membangun Desa. Departemen Pertanian, Jakarta.

Hasbullah, E. L. 2003. Kinerja pertumbuhan dan reproduksi sapi persilangan Simmental dengan Peranakan Ongole dan sapi Peranakan Ongole di Kabupaten Bantul Daerah Istimewa Yogyakarta. Tesis Fakultas Peternakan, Universitas Gadjah Mada, Yogyakarta.

Jesse, G. W., G. B. Thomson, J. L.Clark, H. B. Hedrick and K. G. Weimer. 1976. Effect of ration energy and slaughter weight on composition of empty body and carcass gain of cattle. J. Anim. Sci. 43: 418-425.

Kartadisastra, H. R. 2004. Penyediaan dan Pengelolaan Pakan Ternak Ruminansia. Cetakan ke-8. Kanisius, Yogyakarta.

Lestari, D. 2009. Pengaruh bobot awal terhadap pertambahan bobot badan harian sapi Brahman Cross pada usaha penggemukan di PT. PASINDO, Magelang. Skripsi Fakultas Peternakan, Universitas Gadjah Mada, Yogyakarta.

Mayulu, H., B. Suryanto, Sunarso, M. Christiyanto, F. I. Ballo and Refa'i. 2009. Feasibility of Complete feed Based on Ammonitiated Fermented Rice Straw Utilization on the Beef Cattle Farming. J. I. Tropic. Anim. Agri. 34: 74-78.

NRC. 1976. Nutrient Requirement of Beef Cattle. $6^{\text {th }}$ edn. National Academy Press, Washington DC. 
Parakkasi, A. 1995. IImu Nutrisi dan Makan Ternak Ruminansia. Penerbit Universitas Indonesia, Jakarta.

Prasetiyono, B. W. H. E., Suryahadi, T. Toharmat, dan R. Syarief. 2007. Strategi supplementasi protein ransum sapi potong berbasis jerami dan dedak padi. Media Peternakan 30: 207-217.

Prasetyo, A. B. 2013. Partisipasi pelaksanaan program sarjana membangun desa dalam pengembangan sapi potong di Kabupaten Bantul Daerah Istimewa Yogyakarta. Tesis Fakultas Peternakan, Universitas Gadjah Mada, Yogyakarta

Priyanti, A., I. G. A. P. Mahendri, F. Cahyadi and R. A. Cramb. 2012. Income over feed cost for small-to medium-scale beef cattle fattening operation in East Java. http://www. jppt.undip.ac.id. Accessed 25 September 2013.

Sagala, W. 2011. Analisis biaya pakan dan performa sapi potong local pada ransum hijauan tinggi yang disuplementasi ekstrak lerak (sapindusrarak). Skripsi Fakultas Peternakan, Institut Pertanian Bogor, Bogor.
Sarwono dan B. Arianto, 2001. Penggemukan Sapi dan Kerbau. Agromedia Pustaka. Jakarta.

Siregar, S. 2001. Ransum Ternak Ruminansia. Penebar Swadaya, Jakarta.

Taylor, R. E. 1984. Beef Production and the Beef Industry a Beef Production Perspective. Macmillan Publishing, New York.

Thanh, L. P. and W. Suksombat. 2015. Milk production and income over feed costs in dairy cows fed medium-roasted soybean meal and corn dried distiller's grains with solubles. Asian-Aust. J. Anim. Sci. 28: 519-529.

Tillman, A. D., H. Hartadi, S. Reksohadiprodjo, S. Prawirokusumo, dan S. Lebdosoekojo. 1998. IImu Makanan Ternak Dasar. Cetakan 5. Gadjah Mada Press, Yogyakarta.

Weller, J. I. 1994. Evaluation of genetic differences from profit equations. In: Economic Aspects of Animal Breeding. Chapman \& Hall, London, pp: 78-90. 